\title{
Enhancement of lymphokine-activated killer cell induction using anti-CD25 and anti-CTLA-4 monoclonal antibodies
}

\author{
RIKI OKITA, YOSHIYUKI YAMAGUCHI, AKIKO EMI, KAZUO MATSUURA and TETSUYA TOGE
}

Department of Surgical Oncology, Research Institute for Radiation Biology and Medicine, Hiroshima University, Kasumi 1-2-3, Minami-ku, Hiroshima 734-8553, Japan

Received December 20, 2006; Accepted January 22, 2007

\begin{abstract}
Immunosuppression may contribute to cancer progression, in which regulatory $\mathrm{T}$ ( T-reg) cells have been demonstrated to play important roles. We investigated whether anti-CD25 ( $\alpha$-CD25) monoclonal antibody $(\mathrm{mAb})$ and anticytotoxic T lymphocyte-associated antigen-4 ( $\alpha$-CTLA-4) $\mathrm{mAb}$ could augment in vitro proliferation and cytotoxic activity against cancer cell lines of lymphokine-activated killer (LAK) cells. Human LAK cells with immobilized $\alpha-\mathrm{CD} 3$ Ab plus IL-2 were significantly augmented, including $\mathrm{LAK} / \alpha-\mathrm{CD} 25$ $(10 \mu \mathrm{g} \mathrm{ml}, \mathrm{p}=0.045)$ and LAK $/ \alpha-C T L A-4(5 \mu \mathrm{g} / \mathrm{ml}, \mathrm{p}=0.025$; $10 \mu \mathrm{g} / \mathrm{ml}, \mathrm{p}=0.019)$. LAK $/ \alpha-\mathrm{CD} 25$ and LAK/ $\alpha-$ CTLA-4 showed significant cytotoxic activities against gastric cancer cell lines $(\mathrm{p}<0.05)$. The phenotype of LAK cells showed that $\alpha$-CD25 and $\alpha$-CTLA- 4 mAb more selectively induced the phenotype of $\mathrm{CD}^{+}$cells. The secretion of IFN $-\gamma$ increased significantly in LAK $/ \alpha-C T L A-4(p=0.032) . \alpha-C D 25 \mathrm{mAb}$ reduced intracellular CTLA-4 $(\mathrm{p}=0.0069)$, and $\alpha-\mathrm{CTLA}-4$ $\mathrm{mAb}$ reduced intracellular FOXP3 $(\mathrm{p}=0.049)$, respectively. These results suggest that LAK cells are highly augmented in the presence of $\alpha-\mathrm{CD} 25 \mathrm{mAb}$ and $\alpha$-CTLA- $4 \mathrm{mAb}$ through the possible mechanism of the suppression of T-reg.
\end{abstract}

Correspondence to: Dr Yoshiyuki Yamaguchi, Department of Surgical Oncology, Research Institute for Radiation Biology and Medicine, Hiroshima University, Hiroshima 734-8553, Japan E-mail: shogo@hiroshima-u.ac.jp

Abbreviations: LAK, lymphokine-activated killer; TIL, tumorinfiltrating lymphocyte; CTL, cytotoxic T lymphocyte; DC, dendritic cell; NK cell, natural killer cell; NKT cell, natural killer T cell; T-reg, regulatory T cell; CTLA-4, cytotoxic T lymphocyte-associated antigen-4; mAb, monoclonal antibody; PBMC, peripheral blood mononuclear cell; CFSE, carboxyfluorescein diacetate succinimidyl ester; DI, division index; Per-CP, peridin chlorophyll protein; FITC, fluorescein isothiocyanate; PE, phycoerythrin; GITR, glucocorticoidinduced tumor necrosis factor receptor; CBA, cytometric bead array; AIT, adoptive immunotherapy

Key words: FOXP3, regulatory T cell, lymphokine-activated killer cell, cytotoxic T lymphocyte-associated antigen-4, adoptive immunotherapy, CD25, gastric cancer, cell line, carboxyfluorescein diacetate succinimidyl ester

\section{Introduction}

Adoptive immunotherapy using lymphokine-activated killer (LAK) cells for human cancer was first introduced in 1985 (1), and limited clinical efficacy was demonstrated against renal cell carcinoma and malignant melanoma. Following LAK therapy studies, tumor-infiltrating lymphocyte (TIL) (2), cytotoxic T lymphocytes (CTLs) sensitized with autologous tumor cells (3), peptide-pulsed dendritic cell (DC)-activated killer cells (4), and tumor RNA-induced DC-activated killer cells (5) were introduced into clinics; however, the clinical results of these adoptive immunotherapy trials showed limited efficacy (6). It has been shown that tumor cells acquire an escape mechanism, including the haplotype loss of HLA expression in many types of clinical tumors (7), and disordered antigen processing (8). CTLs therefore fail to recognize these tumor cells, resulting in treatment failure. In this aspect of antigen presentation and recognition, effector cells that are not restricted HLA expression, such as LAK cells (9), NK cells $(9,10)$, NKT cells $(10)$, and $\gamma \delta$ T cells $(11)$, may have an advantage in treating clinical tumors.

Another mechanism, by which tumor cells escape from the immune system, is immunosuppression in the tumorbearing host. It is well understood that immunosuppression may contribute to cancer progression. Recent studies have demonstrated that regulatory $\mathrm{T}$ (T-reg) cells, which have the phenotype of $\mathrm{CD}^{+}{ }^{+} \mathrm{CD} 25^{+}$cells, contribute to immune dysfunction in cancer patients, and a relative increase in $\mathrm{T}$ reg cells is related to tumor progression in patients with esophageal cancer, gastric cancer and non-small cell lung cancer (12-14). Cell-surface molecules, such as CD25, and intracellular molecules, such as cytotoxic $\mathrm{T}$ lymphocyteassociated antigen-4 (CTLA-4), are representative markers on T-reg cells $(15,16)$. T-reg cell attenuation therapy may lead to the establishment of a more effective immunotherapy protocol for cancer patients.

In this study, we aimed to clarify the advantages of applying anti-CD25 ( $\alpha$-CD25) monoclonal antibody (mAb) and $\alpha$-CTLA- 4 mAb to down-modulate T-reg cells in the LAK cell induction system. Our results showed that proliferative responses, secretion of IFN- $\gamma$, and cytotoxic activity of LAK cells were augmented in the presence of $\alpha-\mathrm{CD} 25 \mathrm{mAb}$ and, in particular, $\alpha$-CTLA- 4 mAb, indicating the possibility of novel effector cell generation for adoptive immunotherapy for cancer. 


\section{Materials and methods}

Blood samples and cell isolation. Peripheral blood was collected from 7 healthy volunteers. Written informed consent under an Institutional Review Board-approved protocol was obtained from all subjects before enrollment in the study. Heparinized peripheral blood was obtained and then centrifuged over Lymphoprep (Nycomed Pharma, Norway) gradients for $15 \mathrm{~min}$ at $800 \mathrm{x} \mathrm{g}$ at room temperature. Peripheral blood mononuclear cells (PBMCs) were collected from the interface and washed three times.

Cell lines. MKN-28 (17) and TMK-1 (17) are moderately and poorly differentiated human gastric adenocarcinoma cell lines, respectively. Cells were grown in RPMI-1640 containing $10 \%$ FCS (Gibco, Gaithersburg, MD, USA) in a humidified atmosphere containing $5 \% \mathrm{CO}_{2}$ at $37^{\circ} \mathrm{C}$.

Cell proliferation assay. PBMCs were labeled with $5 \mu \mathrm{M}$ carboxyfluorescein diacetate succinimidyl ester (CFSE, Dojinkagaku, Kumamoto, Japan) for $8 \mathrm{~min}$ at $37^{\circ} \mathrm{C}$ in a humidified $5 \% \mathrm{CO}_{2}$ incubator and washed extensively. PBMCs labeled with CFSE $\left(1 \times 10^{5} / \mathrm{ml}\right)$ were resuspended in RPMI-1640 (Gibco) medium containing $800 \mathrm{IU} / \mathrm{ml}$ IL-2 (TGP-3, Takeda Pharmaceutical Co., Ltd., Osaka, Japan) and 2\% autologous serum, and stimulated to generate LAK cells in a round bottom 96-well tissue culture plate, coated with $1 \mu \mathrm{g} / \mathrm{ml} \alpha-\mathrm{CD} 3 \mathrm{Ab}$ (OKT-3, Kyowahakko, Tokyo, Japan) for more than $48 \mathrm{~h}$ ( $\alpha$-CD3/IL-2 system) and rinsed with RPMI-1640 medium more than three times. The cells were incubated at $37^{\circ} \mathrm{C}$ in a humidified $5 \% \mathrm{CO}_{2}$ incubator for 7 days in the presence of either $5 \mu \mathrm{g} / \mathrm{ml} \alpha-\mathrm{CD} 25 \mathrm{mAb}$ (Ray Biotech, Norcross, GA) $[\mathrm{LAK} / \alpha-\mathrm{CD} 25(5)], 10 \mu \mathrm{g} / \mathrm{ml} \alpha-\mathrm{CD} 25 \mathrm{mAb}[\mathrm{LAK} / \alpha-$ CD25(10)], $5 \mu \mathrm{g} / \mathrm{ml} \mathrm{F}\left(\mathrm{ab}^{\prime}\right) 2 \alpha$-CTLA-4 Ab (Ancell, Bayport, MN) $\left.[L A K / \alpha-C T L A-4(5)], 10 \mu \mathrm{g} / \mathrm{ml} \mathrm{F} \mathrm{ab}^{\prime}\right) 2 \alpha$-CTLA m-4 $\mathrm{Ab}[\mathrm{LAK} / \alpha-\mathrm{CTLA}-4(10)]$ or $10 \mu \mathrm{g} / \mathrm{ml}$ control mouse $\mathrm{Ig}$ (Becton-Dickinson Biosciences, CA, USA) (LAK/Ig). Cells were subjected to flow cytometry, as described below, and proliferative activity was calculated from triplicate samples by the following formula (Fig. 1A) (18):

\section{Division index $(\mathrm{DI})=(100-\mathrm{Y}) / \mathrm{Y}$ \\ $\mathrm{Y}=\mathrm{M} 1+\mathrm{M} 2 / 2+\mathrm{M} 3 / 4+\mathrm{M} 4 / 8+\mathrm{M} 5 / 16+\mathrm{M} 6 / 32+\mathrm{M} 7 / 64+\mathrm{M} 8 / 128$}

Cytotoxic activity of LAK cells against cancer cells. The cytotoxic activity of LAK cells induced either with $\alpha$-CD25 mAb or $\alpha$-CTLA- 4 mAb was investigated using a mixed LAK celltumor cell culture system. Target cells were labeled with $5 \mu \mathrm{M}$ CFSE for $8 \mathrm{~min}$ at $37^{\circ} \mathrm{C}$ in a humidified $5 \% \mathrm{CO}_{2}$ incubator and washed extensively. CFSE-labeled target cancer cells (MKN-28 and TMK-1) $\left(10^{4}\right.$ cells $\left./ \mathrm{ml}\right)$ and various non-labeled LAK cells $\left(10^{5}\right.$ cells $\left./ \mathrm{ml}\right)$, the effector:target ratio $=1: 10$, including LAK, LAK/ $\alpha-C D 25(5), \mathrm{LAK} / \alpha-\mathrm{CD} 25(10), \mathrm{LAK} /$ $\alpha-C T L A-4(5)$, LAK/ $\alpha-C T L A-4(10)$ and LAK/Ig cells, were admixed to a final volume of $2 \mathrm{ml}$ in RPMI-1640 medium with $5 \%$ heat-inactivated FCS in 6-well plates. The samples were incubated in a humidified $5 \% \mathrm{CO}_{2}$ incubator at $37^{\circ} \mathrm{C}$ for 7 days (TMK-1 cells) and 14 days (MKN-28 cells). Cytotoxic activities were calculated from DIs of triplicate samples by the following formula (18):

$$
\text { Cytotoxic activity }=\mathrm{DI} / \mathrm{DI}_{\text {control }} \times 100
$$

Flow cytometry. After 7-day stimulation, CFSE-labeled or nonlabeled LAK cells were washed and resuspended in the medium, and subjected to flow cytometry to determine cell division. Three-color flow cytometry was also performed to determine T-cell phenotypes using $\alpha$-CD3-Per-CP, $\alpha$-CD4FITC, $\alpha$-CD4-PE, $\alpha$-CD4-Per-CP, $\alpha$-CD8-FITC, $\alpha$-CD25-PE and $\alpha$-CD62L-FITC Abs (Becton-Dickinson Biosciences). Flow cytometry was also performed to determine intracellular CTLA-4 and FOXP3. For intracellular staining of 7-day LAK cells with $\alpha$-CTLA-4-PE Ab (Becton-Dickinson Biosciences), cells were fixed and permeabilized using a BD Cytofix/ Cytoperm (Becton-Dickinson Biosciences). Intracellular staining of 7-day LAK cells with $\alpha$-FOXP3-FITC Ab was performed using an anti-human FOXP3 staining set (eBioscience, CA, USA) according to the manufacturer's directions. Flow cytometric analysis was performed on FACSCalibur (BectonDickinson, NJ, USA) and Cell Quest software (BectonDickinson). Lymphocytes were gated on $\mathrm{CD}^{+}$cells or using light scatter. The relative number of lymphocyte populations was expressed as a percentage $(\%)$ of the total number of lymphocytes.

Cytokine assay. Supernatants from the above cultures were harvested and frozen $\left(-20^{\circ} \mathrm{C}\right)$ until further use. Cytokine production of IFN- $\gamma$, TNF- $\alpha$, IL-2, IL-4, IL- 6 and IL-10 was measured using a CBA (Cytometric Bead Array kit, BectonDickinson Biosciences) according to the manufacturer's instructions. The results are expressed as $\mathrm{pg} / \mathrm{ml}$.

Statistical methods. Statistical analyses were performed using the paired and unpaired t-test. Significant difference was determined as $\mathrm{p}<0.05$. Results are expressed as the mean $\pm \mathrm{SD}$.

\section{Results}

$\alpha-C D 25 m A b$ and $\alpha$-CTLA-4 Ab augment proliferation of $L A K$ cells. The proliferative responses of LAK cells generated with $\alpha$-CD3/IL-2 system were assessed in the presence of $\alpha$-CD25 mAb or $\alpha$-CTLA-4 mAb by using CFSE (Fig. 1A). DI of LAK, LAK/ $\alpha-C D 25(5), \mathrm{LAK} / \alpha-\mathrm{CD} 25(10), \mathrm{LAK} / \alpha-$ CTLA-4(5), LAK/ $\alpha$-CTLA-4(10) and LAK/Ig cells were $4.1 \pm 1.7,4.5 \pm 1.6,4.6 \pm 1.8,4.4 \pm 1.7,4.4 \pm 1.5$ and $3.9 \pm 1.4$, respectively (Fig. 1B). There were significant increases in DI of LAK/ $\alpha-C D 25(10)(p=0.045), L A K / \alpha-C T L A-4(5)$ $(\mathrm{p}=0.025)$ and LAK/ $\alpha-\mathrm{CTLA}-4(10)$ cells $(\mathrm{p}=0.019)$ compared with that of control LAK cells.

Cytotoxic activity of LAK cells induced with $\alpha$-CD25 $m A b$ and $\alpha$-CTLA-4 $A b$. The cytotoxic activities of LAK cells were investigated (Fig. 2). MKN-28 cells and TMK-1 cells admixed with $\mathrm{LAK}, \mathrm{LAK} / \alpha-\mathrm{CD} 25(10)$ and $\mathrm{LAK} / \mathrm{Ig}$ cells grew and formed innumerable colonies. In contrast, both cancer cells co-cultured with LAK/ $\alpha$-CTLA-4(10) cells could not form colonies (Fig. 2A and B). DIs of MKN-28 cancer cells admixed with LAK, LAK/ $\alpha$-CD25(10), LAK/ $\alpha$-CTLA$4(10)$ and LAK/Ig cells were $100 \%, 73.0 \pm 10.7 \%(\mathrm{p}=0.049)$, $46.1 \pm 1.5 \%,(\mathrm{p}=0.0003)$ and $75.6 \pm 15.6 \%$, respectively (Fig. 2C), and those of TMK-1 cancer cells were $100 \%, 94.2 \pm 10.9 \%$, 
A
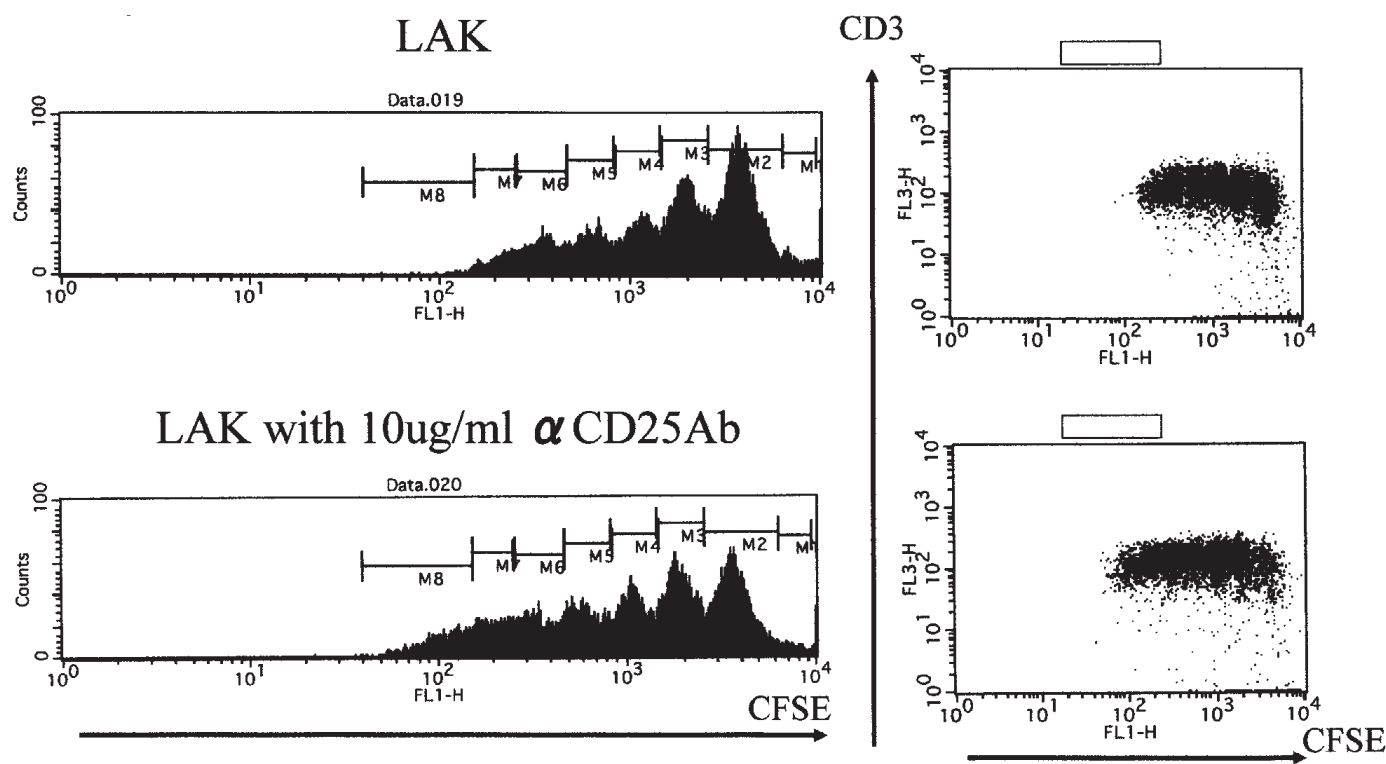

Division Index $(D I)=(100-\mathrm{Y}) / \mathrm{Y}$
$\mathrm{Y}=\mathrm{M} 1+\mathrm{M} 2 / 2+\mathrm{M} 3 / 4+\mathrm{M} 4 / 8+\mathrm{M} 5 / 16+\mathrm{M} 6 / 32+\mathrm{M} 7 / 64+\mathrm{M} 8 / 128$

B

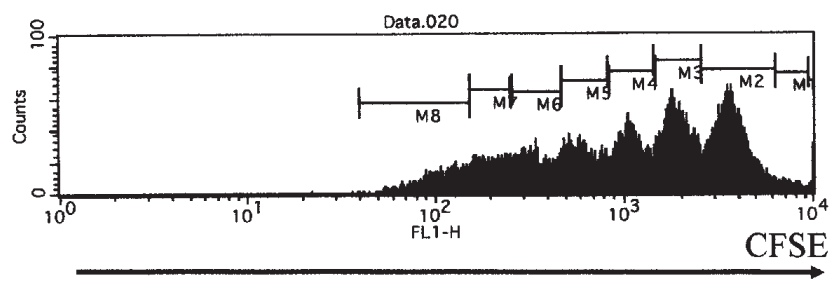

LAK with $10 \mathrm{ug} / \mathrm{ml} \alpha \mathrm{CD} 25 \mathrm{Ab}$

DI: division Index

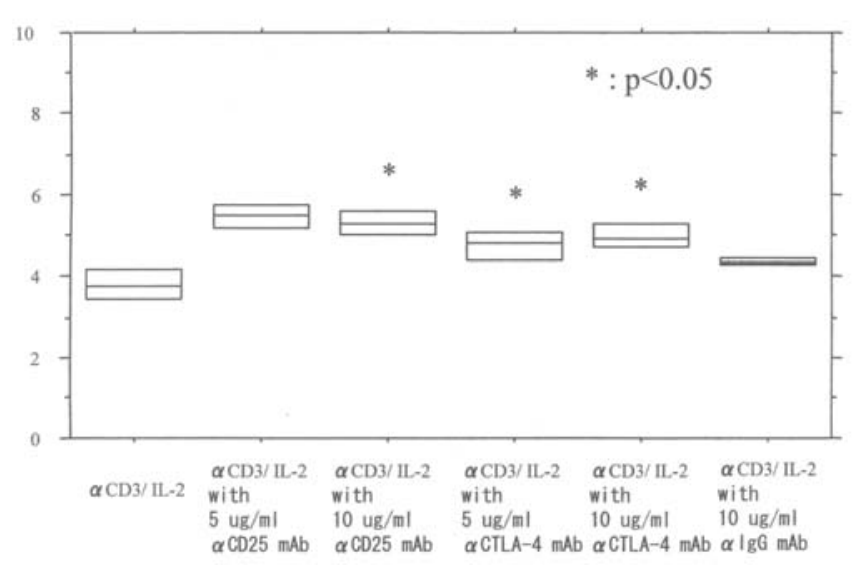

Figure 1. Proliferation analysis of lymphokine-activated killer (LAK) cells using carboxyfluorescein diacetate succinimidyl ester (CFSE). (A) Formula of division index (DI) and histogram of cell division. PBMCs were labeled with CFSE and stimulated with $\alpha$-CD3/IL-2 system to generate LAK cells in the absence (upper) or presence (lower) of $\alpha-\mathrm{CD} 25 \mathrm{mAb}$. DIs of LAK cells were assessed on flow cytometry and calculated as a formula. (B) DIs of LAK, LAK/ $\alpha-C D 25$, LAK/ $\alpha-C T L A-4$ and LAK/Ig cells $(n=3)$. Significant difference, ${ }^{*} \mathrm{p}<0.05$.

$53.6 \pm 7.0 \%(\mathrm{p}=0.0075)$ and $97.4 \pm 11.3 \%$, respectively (Fig. 2D). A significant increase of cytotoxic activity was observed in LAK/ $\alpha-C T L A-4(10)$ cells against both tumor cells and in $\mathrm{LAK} / \alpha-\mathrm{CD} 25(10)$ cells against MKN-28 cells compared to LAK cells.

Phenotypes of LAK cells stimulated with $\alpha-C D 25 \mathrm{mAb}$ and $\alpha$-CTLA-4 Ab. Flow cytometric analysis was performed to determine the phenotypes of LAK cells induced with $\alpha$-CD25 $\mathrm{mAb}$ and $\alpha$-CTLA-4 mAb (Fig. 3). CD4 ${ }^{+}$cells in LAK, LAK/ $\alpha-\mathrm{CD} 25(10), \mathrm{LAK} / \alpha-\mathrm{CTLA}-4(10)$, and LAK/Ig cells were
$33.8,20.4,13.6$ and $23.2 \%$, respectively. On the other hand, $\mathrm{CD}^{+} \mathrm{T}$ cells in LAK, LAK/ $\alpha-\mathrm{CD} 25(10), \mathrm{LAK} / \alpha-\mathrm{CTLA}-4(10)$, and $\mathrm{LAK} / \operatorname{Ig}(10)$ cells were $59.1,74.2,81.5$ and $69.0 \%$, respectively (Fig. 3A-D).

We next analyzed CD25+ and CD62 $\mathrm{L}^{+}$cells in $\mathrm{LAK}$ cells (Fig. 3E-H). The phenotypes of $\mathrm{CD} 4{ }^{+} \mathrm{CD} 25^{+}$and $\mathrm{CD}^{+}{ }^{+} \mathrm{CD} 25^{+} \mathrm{CD} 62 \mathrm{~L}^{+}$cells in $\mathrm{LAK}$ cells were 62.9 and $49.4 \%$, respectively. On the other hand, in LAK/ $\alpha$-CTLA-4(10) cells, the phenotypes of $\mathrm{CD} 4{ }^{+} \mathrm{CD} 25^{+}$, and $\mathrm{CD} 4{ }^{+} \mathrm{CD} 25^{+} \mathrm{CD} 62 \mathrm{~L}^{+}$ cells were 68.7 and $53.8 \%$, respectively.

$\alpha-C D 25 m A b$ and $\alpha-C T L A-4$ Ab augment IFN- $\gamma$ secretion of $L A K$ cells. IFN- $\gamma$ production of LAK cells was examined in the presence of $\alpha$-CD25 mAb or $\alpha$-CTLA- 4 Ab using CBA (Fig. 4). The secretion of IFN- $\gamma$ from LAK, LAK/ $\alpha-C D 25(5)$, LAK/ $\alpha$-CD25(10), LAK/ $\alpha-C T L A-4(5)$, LAK/ $\alpha-C T L A-4(10)$ and LAK/Ig cells was $4664 \pm 1062,5454 \pm 1240,5741 \pm 772$, $5800 \pm 741,5893 \pm 439$ and $5171 \pm 1780 \mathrm{pg} / \mathrm{ml}$, respectively. Significantly higher levels of IFN- $\gamma$ production were observed in LAK/ $\alpha$-CTLA-4(10) cells compared to LAK cells ( $\mathrm{p}=0.032$ ). All other cytokine levels showed no significant change (data not shown $)(n=3)$.

$\alpha$-CD25 mAb reduced intracellular CTLA-4 and $\alpha-C T L A-4$ $A b$ reduced intracellular FOXP3 in 7-day LAK. Flow cytometric analysis was performed to determine the intracellular CTLA-4 and FOXP3 expression of 7-day LAK cells (Fig. 5). Intracellular CTLA- $4^{+}$cells in LAK, LAK/ $\alpha-C D 25(10)$, LAK/ $\alpha$-CTLA-4(10) and LAK/Ig cells were $31.3 \pm 0.8,24.8 \pm 8.7$, $37 \pm 12.7$ and $35.8 \pm 7.0 \%$, respectively. On the other hand, intracellular FOXP3 ${ }^{+}$cells in LAK, LAK/ $\alpha-C D 25(10), \mathrm{LAK} / \alpha-$ CTLA-4(10) and LAK/Ig cells were 83.3 $\pm 2.5,84.4 \pm 2.7$, $77.1 \pm 4.2$ and $83.2 \pm 4.2 \%$, respectively. Intracellular CTLA-4 ${ }^{+}$ cells were significantly reduced in $\mathrm{LAK} / \alpha-\mathrm{CD} 25(10)$ cells 
A: $\mathrm{MKN}-28$

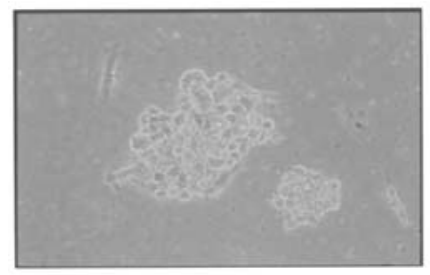

LAK alone

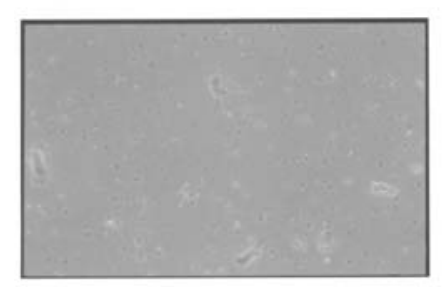

LAK with

$\alpha$ CTLA-4 Ab
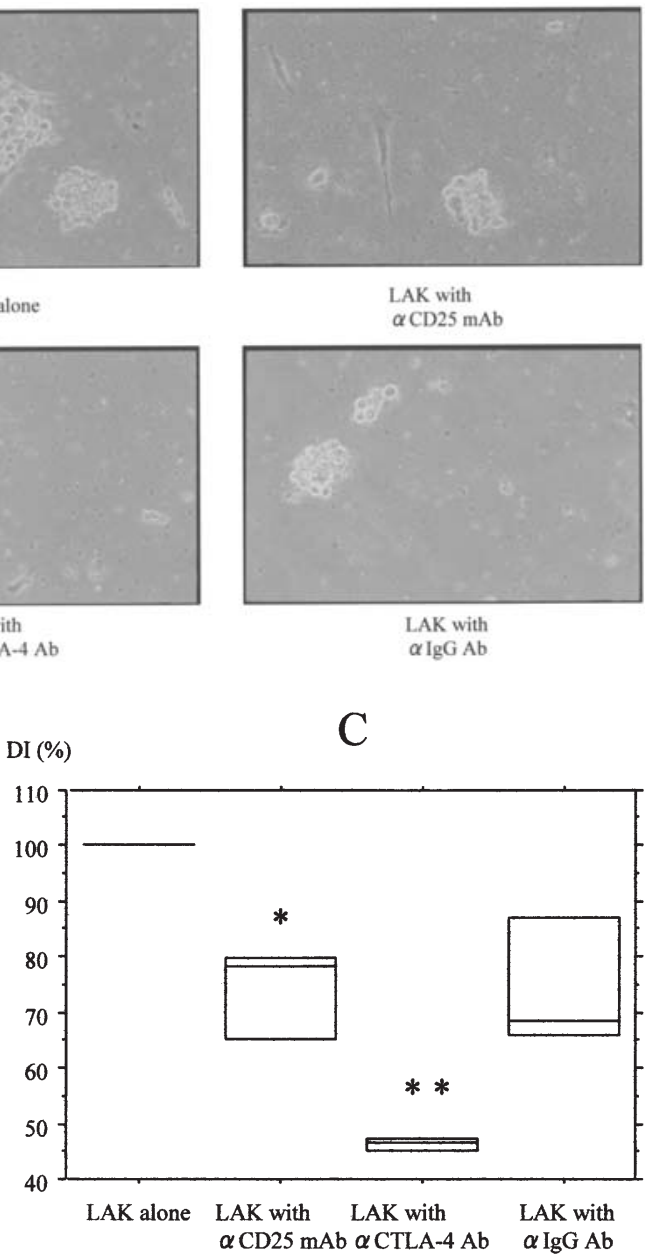

LAK with $\alpha \mathrm{CD} 25 \mathrm{mAb}$

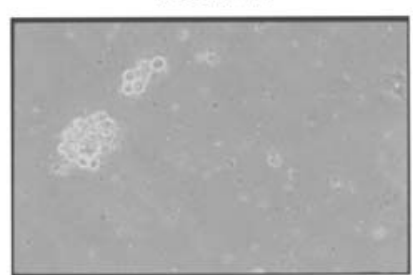
LAK with
$\alpha \mathrm{IgG} \mathrm{Ab}$
B: TMK-1

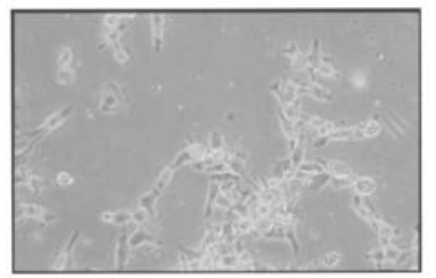

LAK alone

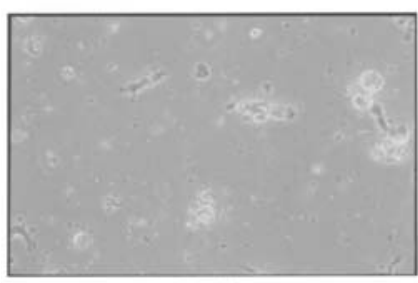

LAK with

$\alpha$ CTLA-4 Ab

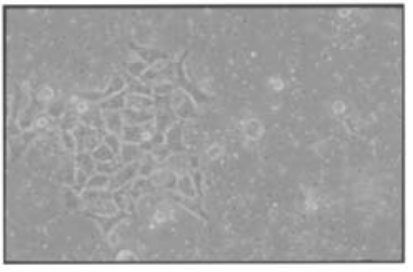

LAK with

$\alpha \mathrm{CD} 25 \mathrm{mAb}$

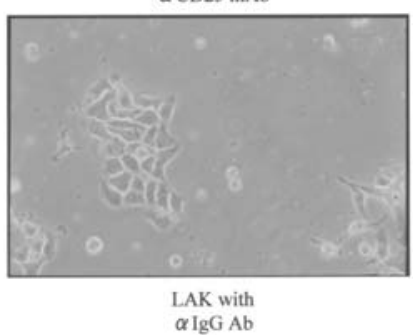

D

DI (\%)

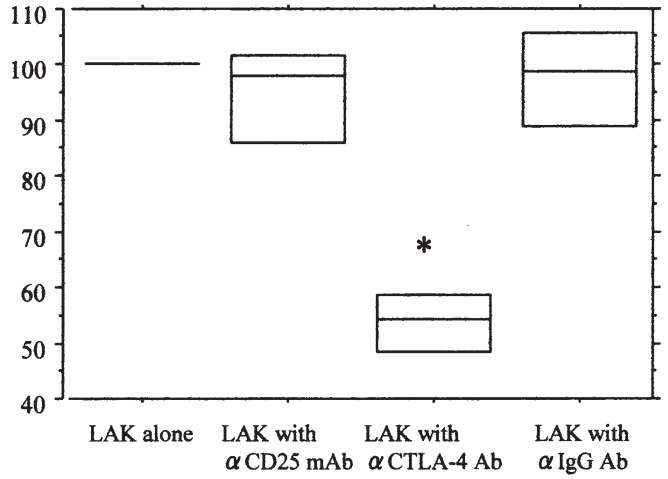

\section{MKN-28}

\section{TMK-1}

Figure 2. Cytotoxic activity of LAK cells. CFSE-labeled MKN-28 (A) or TMK-1 (B) tumor cells were admixed with LAK, LAK/ $\alpha$-CD25, LAK/ $\alpha$-CTLA-4 and LAK/Ig cells, and observed by phase-contrast microscopy (A and B). DIs of MKN-28 (C) or TMK-1 (D) cells were determined on flow cytometry. Analyses were calculated from triplicate samples.

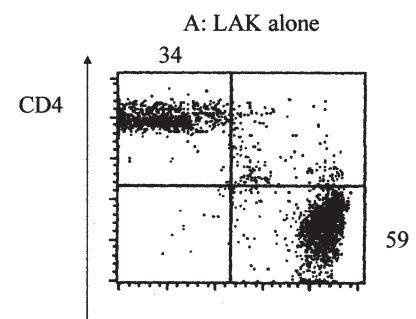

C: LAK with $\alpha$ CTLA-4 mAb

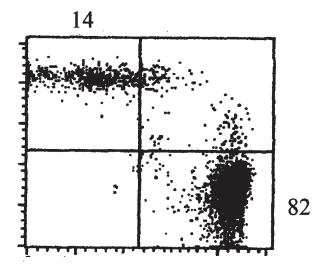

B: LAK with $\alpha$ CD25 mAb

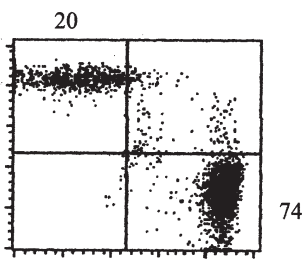

D: LAK with $\alpha$ IgG mAb

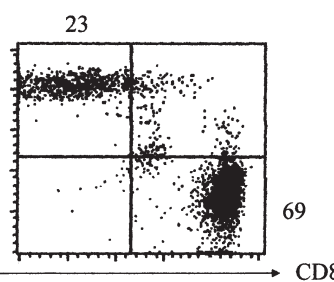

E: LAK alone

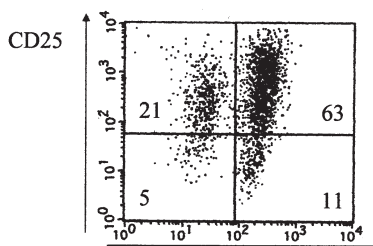

G: LAK alone

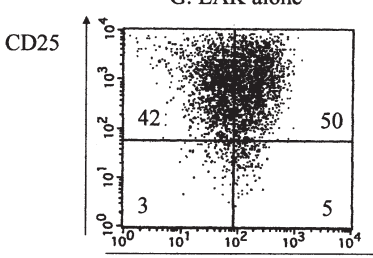

F: LAK with $\alpha$ CTLA- 4 mAb

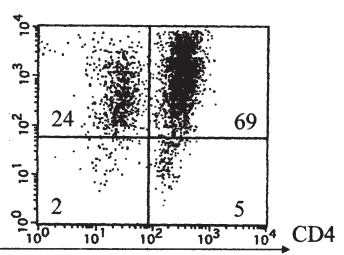

H: LAK with $\alpha$ CTLA-4 mAb

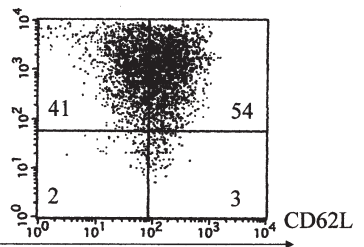

Figure 3. Phenotype analysis on LAK cells. LAK cells were induced with or without $\alpha-\mathrm{CD} 25 \mathrm{mAb}, \alpha-\mathrm{CTLA}-4 \mathrm{mAb}$, and LAK/Ig, and stained with Abs as indicated. Flow cytometric analysis was performed on FACScalibur after gating on CD3 ${ }^{+}$cells. CD4 vs CD8 (A-D); CD4 vs CD25 (E, F); and CD62L vs CD25 $(\mathrm{G}, \mathrm{H})$. Analyses were calculated from triplicate samples. 


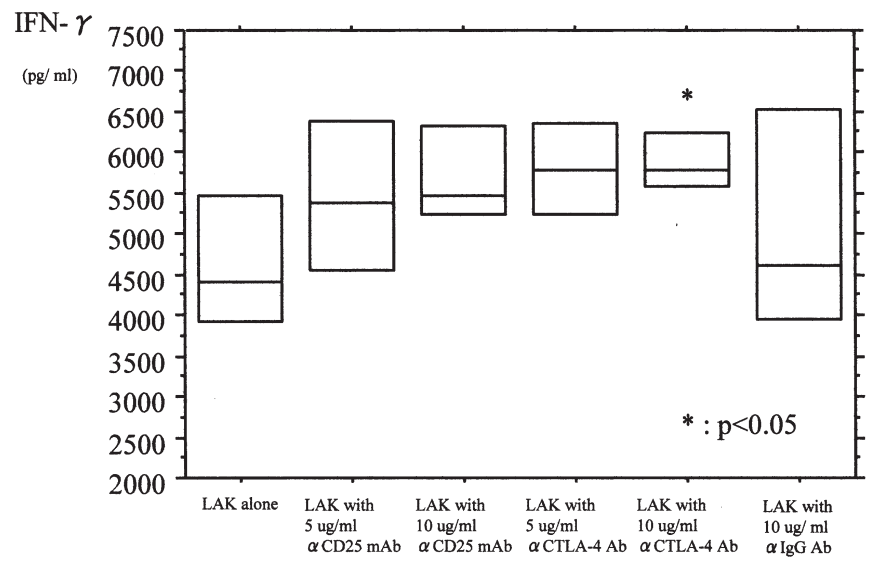

Figure 4. IFN- $\gamma$ production of LAK cells. LAK cells were induced with or without $\alpha$-CD25 mAb, $\alpha$-CTLA- 4 mAb, and LAK/Ig, and IFN- $\gamma$ production in the culture supernatant was measured $(n=3)$. Significant difference, ${ }^{*} \mathrm{p}<0.05$.

$(\mathrm{p}=0.0069)$ (Fig. 5A), and intracellular FOXP3 ${ }^{+}$cells were significantly reduced in LAK/ $\alpha-C T L A-4(10)$ cells $(\mathrm{p}=0.049)$ compared to LAK/Ig cells (Fig. 5B).

\section{Discussion}

After the discovery of T-reg cells (15), increasing attention has focussed on T-reg cell down-modulation combination in cancer immunotherapy. Dudley et al reported that adoptive cell transfer therapy following non-myeloablative but lymphodepleting chemotherapy can mediate significant tumor regression in patients with metastatic melanoma (19). In that study, the average $\mathrm{CD}^{+}$cell counts fell and did not recover for almost 6 months, whereas the average $\mathrm{CD}^{+}$cell counts transiently rose in lymphodepleting chemotherapy, suggesting the possible attenuation of T-reg cells by non-myeloablative lymphodepleting chemotherapy (19). Several molecules, including CD25 (15), CTLA-4 (16), GITR (20) and FOXP3 (21) can be a target of T-reg cell depletion or functional inactivation. Clinical studies of tumor-specific peptide vaccination therapy combined with fully humanized $\alpha$-CTLA- 4 Ab have been reported and showed both cancer regression and severe autoimmunity (22). Administration of diphtheria toxinconjugated recombinant IL-2, which selectively eliminates CD25-expressing T-reg cells, in tumor RNA-transfected DC vaccination therapy, showed improved tumor-specific $\mathrm{T}$ cell responses (23). In this study, we investigated ex vivo stimulation of PBMCs with $\alpha$-CD3/IL- 2 culture system in the presence of $\alpha$-CD25 mAb and $\alpha$-CTLA- $4 \mathrm{mAb}$, and demonstrated enhanced cell proliferation and cyto-toxic activity against tumor cells. Although CD25 and CTLA-4 are not specific markers expressed on T-reg cells as they can be also expressed on activated $\mathrm{T}$ cells, such as CTLs, the expression of CD25 and CTLA-4 molecules on T-reg cells is relatively and constitutively high (24), indicating the possibility of targeting CD25 and CTLA-4 molecules for downmodulating T-reg cells. Moreover, Kudo et al have shown that the administration of $\alpha-\mathrm{CD} 25 \mathrm{mAb}$ at the time of vaccination reduced the number of $\mathrm{CD} 4{ }^{+} \mathrm{CD} 25^{+}$cells, but simultaneously enhanced vaccine-induced $\mathrm{CD} 4^{+}$cells and $\mathrm{CD}^{+} \mathrm{T}$ cell responses, thus apparently not having an inhibitory effect on activated $\mathrm{T}$ cell responses (25). This observation also suggests that $\alpha$-CD25 mAb and $\alpha$-CTLA- 4 mAb may regulate T-reg cells more selectively at the pre-activation phase of lymphocytes compared to the post-activation phase. Therefore, we investigated LAK cell generation combined with T-reg cell modulation by $\alpha$-CD25 mAb and $\alpha$-CTLA- 4 mAb ex vivo at the beginning of LAK cell induction.

Our data showed that $\alpha-C D 25$ mAb therapy enhanced LAK cell proliferation and cytotoxic activity against cancer cell lines. Shimizu et al have reported that $\alpha-\mathrm{CD} 25 \mathrm{mAb}$ therapy augments anti-tumor immunity by the depletion of T-reg cells (20); however, a recent study reported that $\alpha$-CD25 $\mathrm{mAb}$ failed to physically deplete T-reg cells but down-regulated and/or induced shedding of CD25 from the surface of T-reg cells (26). It has also been demonstrated that interruption of the IL-2R/IL-2 signaling pathway blocks T-reg cell effector function (27), indicating that $\alpha-C D 25 \mathrm{mAb}$ induces the functional inactivation of T-reg cells. Moreover, we showed that $\alpha-C D 25 \mathrm{mAb}$ treatment significantly reduced intracellular CTLA-4 in 7-day LAK cells. The negative immunoregulatory function of CTLA-4 has been definitively demonstrated in
A

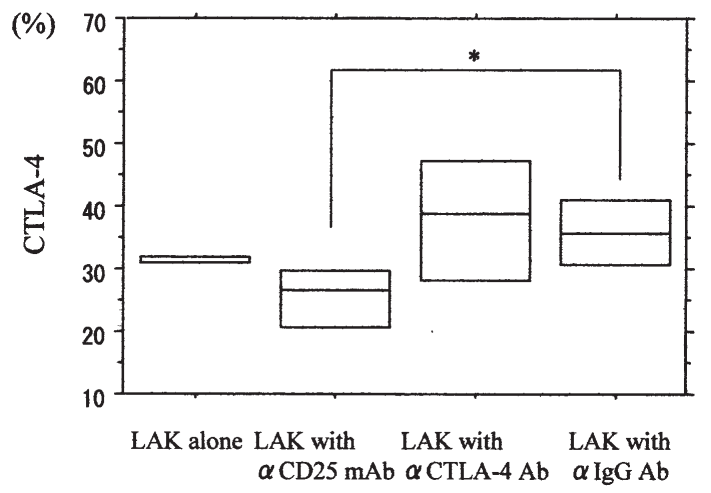

B

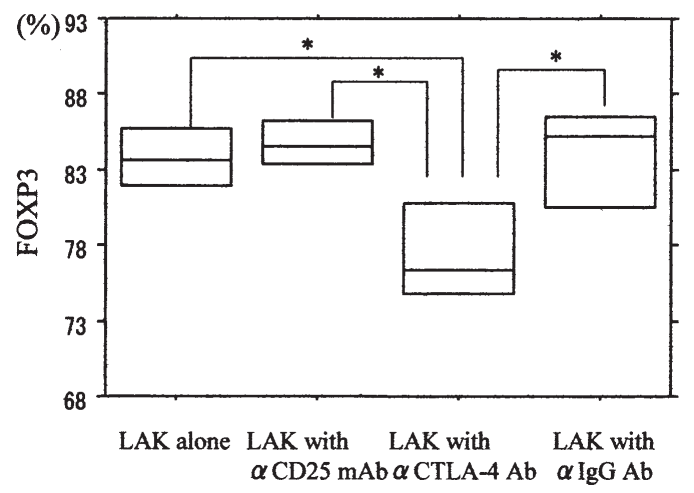

Figure 5. CTLA-4 and FOXP3 expression of LAK cells. LAK cells were induced with or without $\alpha$-CD25 mAb, $\alpha$-CTLA-4 mAb, and LAK/Ig, and intracellular expression of CTLA-4 or FOXP3 was stained. Flow cytometric analysis was performed on FACScalibur after gating on lymphocyte (n=3). Significant difference, ${ }^{*} \mathrm{p}<0.05$. 
CTLA-4-deficient mice that developed lethal lymphoproliferative disease with infiltration of visceral organs by activated $\mathrm{T}$ cells (28). These studies suggest that $\alpha-\mathrm{CD} 25 \mathrm{mAb}$ may augment LAK cell induction by down-modulation of T-reg cell function and CTLA-4 molecules.

On the other hand, our data showed that $\alpha$-CTLA- 4 mAb therapy enhanced not only LAK cell proliferation and cytotoxic activity against cancer cell lines, but also secretion of IFN- $\gamma$. It has been demonstrated that most cancer patients do not develop a satisfactory immunological anti-tumor response due to several mechanisms, such as T-cell dysfunction and the marked impairment of IFN- $\gamma$ secretion (29). Phan et al have demonstrated the restoration of T-cell immunity and anti-tumor responses by $\alpha$-CTLA- 4 mAb treatment (22). Our results that IFN- $\gamma$ production from LAK cells could be enhanced using $\alpha$-CTLA- 4 mAb may explain the mechanisms of the restoration of T-cell dysfunction in cancer patients by blockade of the CTLA-4 molecule. In addition, $\alpha$-CTLA-4 $\mathrm{mAb}$ therapy selectively induced the cell proliferation of $\mathrm{CD}^{+} \mathrm{T}$ cells, but reduced $\mathrm{CD} 4^{+} \mathrm{T}$ cells and the induction of $\mathrm{CD} 25^{+}$and $\mathrm{CD} 62 \mathrm{~L}^{+}$cells. This indicated the enhancement of T-cell activation and chemotaxis ex vivo (30). Additionally, $\alpha$-CTLA-4 mAb treatment significantly reduced intracellular FOXP3, a master gene of T-reg cells, in 7-day LAK cells. Taken together, these findings support an important mechanism of augmenting LAK cell function; that $\alpha$-CTLA-4 $\mathrm{mAb}$ treatment, as well as $\alpha-\mathrm{CD} 25 \mathrm{mAb}$, may deplete and/or functionally inactivate FOXP3 ${ }^{+}$T-reg cells.

The most important finding was that LAK cell cytotoxic activities against cancer cell lines were modestly augmented with $\alpha-C D 25 \mathrm{mAb}$ and $\alpha$-CTLA-4 mAb. LAK/ $\alpha-C T L A-4(10)$ cells particularly showed preferential proliferation of $\mathrm{CD}^{+}$ $\mathrm{T}$ cells, $\mathrm{CD} 25^{+}$and $\mathrm{CD} 62 \mathrm{~L}^{+}$-activated T cells, and enhanced IFN- $\gamma$ production, suggesting the possible clinical use of these 'hyper' LAK cells for AIT of cancer. It remains an important question to identify the molecules that these LAK cells recognize. Phan et al (22) have reported that effector cells induced in vivo with tumor-specific peptide vaccine in combination with $\alpha$-CTLA-4 mAb recognize tumor antigens as well as self antigens, resulting in severe autoimmune diseases. Although we did not use antigen-presenting cells and antigens to generate LAK cells in vitro, our LAK cells may be reactive with self antigens, but this remains to be elucidated. Regarding the tumor escape mechanism, AIT using HLA-non-restricted effector cells may be indistinguishable in advances in tumor response when orchestrated with HLA-restricted approaches. Clinical trials of AIT using LAK cells are now in progress for the possible treatment of patients with metastatic cancer.

\section{Acknowledgements}

We thank Dr K. Konishi for excellent technical advice, and Ms. Y. Nakatani, M. Funada, M. Okamura and N. Miyashita for their excellent technical assistance.

\section{References}

1. Rosenberg SA, Lotze MT, Muul LM, et al: Observation on the systemic administration of autologous lymphokine-activated killer cells and recombinant interleukin-2 to patients with metastatic cancer. N Engl J Med 313: 1485-1492, 1985.
2. Rosenberg SA, Packard BS, Aebersold PM, et al: Use of tumor infiltrating lymphocytes and interleukin- 2 in the immunotherapy of patients with metastatic melanoma. A preliminary report. $\mathrm{N}$ Engl J Med 319: 1676-1680, 1988.

3. Aruga A, Yamauchi K, Takasaki K, et al: Induction of autologous tumor-specific cytotoxic $\mathrm{T}$ cells in patients with liver cancer. Int J Cancer 49: 19-24, 1991.

4. Kono K, Takahashi A, Sugai H, et al: Dendritic cells pulsed with HER-2/neu-derived peptides can induce specific T-cell responses in patients with gastric cancer. Clin Cancer Res 8: 3394-3400, 2002.

5. Boczkowski D, Nair SK, Synder D, et al: Dendritic cells pulsed with RNA are potent antigen-presenting cells in vitro and in vivo. J Exp Med 184: 465-472, 1996.

6. Yamaguchi Y, Ohshita A, Kawabuchi Y, et al: Adoptive immunotherapy of cancer using activated autologous lymphocytes current status and new strategies. Hum Cell 16: 183-189, 2003.

7. Marincola FM, Jaffee EM, Hicklin DJ and Ferrone S: Escape of human solid tumors from T-cell recognition, molecular mechanisms and functional significance. Adv Immunol 74: 181-273, 2000.

8. Lou Y, Vitalis TZ, Basha G, et al: Restoration of the expression of transporters associated with antigen processing in lung carcinoma increases tumor-specific immune responses and survival. Cancer Res 65: 7926-7933, 2005.

9. Salvucci O, Kolb JP, Dugas B, Dugas N and Chouaib S: The induction of nitric oxide by interleukin-12 and tumor necrosis factor- $\alpha$ in human natural killer cells, relationship with the regulation of lytic activity. Blood 92: 2093-2102, 1998.

10. Smyth MJ, Thia KY, Street SE, et al: Differential tumor surveillance by natural killer (NK) and NKT cells. J Exp Med 191: 661-668, 2000.

11. Kato Y, Tanaka Y, Miyagawa F, Yamashita S and Minato N: Targeting of tumor sells for human $\gamma \delta \mathrm{T}$ cell by non-peptide antigens. J Immunol 167: 5092-5098, 2001.

12. Wolf AM, Wolf D, Steurer M, et al: Increase of regulatory $\mathrm{T}$ cells in the peripheral blood of cancer patients. Clin Cancer Res 9: 606-612, 2003.

13. Ichihara $\mathrm{F}$, Kono $\mathrm{K}$, Takahashi $\mathrm{A}$, et al: Increased populations of regulatory $\mathrm{T}$ cells in peripheral blood and tumor-infiltrating lymphocytes in patients with gastric and esophageal cancers. Clin Cancer Res 9: 4404-4408, 2003.

14. Okita R, Saeki T, Takashima S, Yamaguchi Y and Toge T: $\mathrm{CD} 4{ }^{+} \mathrm{CD} 25^{+}$regulatory $\mathrm{T}$ cells in the peripheral blood of patients with breast cancer and non-small cell lung cancer. Oncol Rep 14: 1269-1273, 2005.

15. Sakaguchi S, Sakaguchi N, Asano M, et al: Immunologic selftolerance maintained activated $\mathrm{T}$ cells expressing IL-2 receptor $\alpha$-chains (CD25), breakdown of a single mechanism of selftolerance caused various autoimmune diseases. J Immunol 155: 1151-1164, 1995.

16. Read S, Malmstrom V and Powrie F: Cytotoxic T lymphocyteassociated antigen 4 plays an essential role in the function of $\mathrm{CD} 25(+) \mathrm{CD} 4(+)$ regulatory cells that control intestinal inflammation. J Exp Med 192: 295-302, 2000.

17. Akagi M, Yokozaki H, Kitadai Y, et al: Expression of amphiregulin in human gastric cancer cell lines. Cancer 75 : 1460-1466, 1995.

18. Augulo R and Fulcher DA: Measurement of Candida-specific blastogenesis, comparison of carboxyfluorescein succinimidyi ester labeling of $\mathrm{T}$ cell, Thymidine incorporation and CD69 expression. Cytometry 34: 143-151, 1998.

19. Dudley ME, Wunderlich JR, Yang JC, et al: Adoptive cell transfer therapy following non-myeloablative but lymphodepleting chemotherapy for the treatment of patients with refractory metastatic melanoma. J Clin Oncol 23: 2346-2357, 2005.

20. Shimizu J, Yamasaki S and Sakaguchi S: Induction of tumor immunity by removing $\mathrm{CD} 25^{+} \mathrm{CD} 4^{+} \mathrm{T}$ cells, a common basis between tumor immunity and autoimmunity. J Immunol 163: 5211-5218, 1999.

21. Hori S, Nomura T and Sakaguchi S: Control of regulatory T cell development by the transcription factor FOXP3. Science 299: 1057-1061, 2003.

22. Phan GQ, Yang JC, Sherry RM, et al: Cancer regression and autoimmunity induced by cytotoxic $\mathrm{T}$ lymphocyte-associated antigen 4 blockade in patients with metastatic melanoma. Proc Natl Acad Sci USA 100: 8372-8377, 2003.

23. Dannull J, Su Z, Rizzieri D, et al: Enhancement of vaccinemediated antitumor immunity in cancer patients after depletion of regulatory T cells. J Clin Invest 115: 3623-3633, 2005. 
24. Allouche M, Sahraoui Y, Augery-Bourget Y, et al: Interleukin 2 receptors. Leuk Res 14: 699-703, 1990.

25. Kudo-Saito C, Schlom J, Camphausen K, et al: The requirement of multimodal therapy (vaccine, local tumor radiation and reduction of suppressor cells) to eliminate established tumors. Clin Cancer Res 11: 4533-4544, 2005.

26. Kohm AP, McMahon JS, Podojil JR, et al: Anti-CD25 monoclonal antibody injection results in the functional inactivation, not depletion, of $\mathrm{CD} 4^{+} \mathrm{CD} 25^{+} \mathrm{T}$ regulatory cells. J Immunol 176: 3301-3305, 2006

27. Thornton CA, Upham JW, Wikstrom ME, et al: IL-2 is critically required for the in vitro activation of $\mathrm{CD}^{+} \mathrm{CD} 25^{+} \mathrm{T}$ cell suppressor function. J Immunol 172: 6519-6523, 2004.
28. Waterhouse P, Penninger JM, Timms E, et al: Lymphoproliferative disorders with early lethality in .mice deficient in Ctla-4. Science 270: 985-988, 1995.

29. Thornton AM and Shevach EM: CD $4^{+} \mathrm{CD} 25^{+}$immunoregulatory $\mathrm{T}$ cells suppress polyclonal $\mathrm{T}$ cell activation in vitro by inhibiting interleukin 2 production. J Exp Med 188: 287-296, 1998.

30. Fu S, Yopp AC, Mao X, et al: $\mathrm{CD} 4{ }^{+} \mathrm{CD} 25^{+} \mathrm{CD} 62 \mathrm{~L}^{+} \mathrm{T}-$ regulatory cell subset has optimal suppressive and proliferative potential. Am J Transplant 4: 65-78, 2004. 